\title{
Microscopic Structural Alterations in Response to Mesenchymal Stem Cells Injection in Experimentally Induced Oligospermia in Adult Rat Testis (Histological and Immunohistochemical Study)
}

\section{Original Article}

\author{
Sherifa Abd El-Salam ${ }^{1}$,Eman Mohamed Faruk ${ }^{1}$,Samia Mahmoud Manawy ${ }^{2}$ and \\ Naglaa Yehia Nafie ${ }^{3}$
}

Departments of Histology and Cytologyl, Departments of Anatomy and physiology,

\author{
Department of Physiology ${ }^{3}$, Faculty of Medicine, Benha University
}

\begin{abstract}
Background: Lead is one of the heavy metals that has many side effects on different organs. Recently, infertility among both men and women has become a major concern. Transplantation of mesenchymal stem cells to the male reproductive organ is used for curing various diseases.

Aim of the work: The aim of the present work is to study the microscopic structural variations and immunohistochemical appearance of the effects of mesenchymal stem cells transplantation (MSCs) on oligospermia induced in adult male albino rats.

Material and methods: Thirty-two adult male rats were divided into; Group I (control group-ten rats), group II, twelve rats injected intravenously by a single dose of lead nitrate (LN, $23.3 \mathrm{mg} / \mathrm{kg}$ body weight) and group III (L N with MSCs) ten rats injected intravenously for six weeks. Sperm analysis, hormonal assay and testicular samples were taken for histological, immunohistochemical and statistical analysis at the end of the study.

Results: The results revealed that the mean percentage of sperm count, sperm motility and testosterone levels were significantly affected after LN toxicity with apparent changes in the histological pattern of the seminiferous tubules which showed distortion, abnormal distribution, vacuolation, deeply stained nuclei (apoptotic nuclei) and detachment of spermatogenic cells from the germinal epithelium in comparison to the control group. Immunohistochemical study showed that a significant elevation of the intensity of caspase-3 immunostaining in Sertoli, Leydig and peritubular myoid cells in comparison to that of the control group. MSCs injection after lead toxicity showed significant improvement in sperm analysis (count, motility, abnormality and morphology) with marked improvement in histological changes as well as decrease in the mean area $\%$ of caspase -3 immune reaction.

Conclusion: MCSs partially prevent testicular degenerative changes induced by lead toxicity, suggesting that the MSCs may give hope in the treatment of male infertility.
\end{abstract}

Received: 18 February 2019, Accepted: 20 April 2019

Key Words: Caspase-3, oligospermia, lead, stem cells.

Corresponding Author: Eman Mohamed Faruk, M.D, Department of Histology and Cell Biology, Faculty of Medicine, Benha University, Benha, Egypt, Tel.: +20 133221937 - +96 6596640779, E-mail: faruk_eman@yahoo.com

ISSN: 1110-0559, Vol. 42, No. 4

\section{INTRODUCTION}

Infertility in both male and female has a major interest as it affects nearly twenty percent of the population all over the world. Male factors are responsible for a large percent of infertility cases ${ }^{[1]}$.

Spermatogenesis and factors affecting it are so important to study the causes and mechanism of male infertility ${ }^{[2]}$.

Metals are special environmental intoxicants because they tend to cause accumulative properties in the body and lead to serious hazards to vital systems ${ }^{[3]}$. Lead $(\mathrm{Pb})$ is one of the most common metals with wide uses by different methods especially in industrial uses ${ }^{[4]}$.
One of the main toxicological effect of lead is male infertility ${ }^{[5]}$, as other studies proved that lead can pass the blood -testis barrier causes impairment of differentiation of germ cells and so affects spermatogenesis ${ }^{[6]}$. The more susceptible to lead toxicity are workers who are under risk of a decrease in semen amount, sperm count and motility ${ }^{[7,8]}$. lead toxicity causes oxidative stress and the generation of more reactive oxygen species (ROS) that affect all tissues ${ }^{[9,10]}$.

Stem cells have a capacity of differentiation and selfrenewal into different cell types on exposure to a special stimulus $^{[11]}$. 
Mesenchymal stem cells (MSCs) are defined as adult stem cells originated from bone marrow. They are known as multipotent cells and consider as the best choice for therapeutic purposes due to their ability to differentiate to different cell types ${ }^{[12,13]}$.

The studies on andrology research showed that the stem cells which were taken from human umbilical cord have the ability to differentiate into sperm-like cells ${ }^{[14,15]}$.

Some researchers studied the ability of differentiation of MSCs into different cells as Leydig cells and Sertoli cells $^{[16]}$.

This study was done to investigate the effects of MSCs on experimentally induced oligospermia in adult male albino rats.

\section{MATERIALS AND METHODS}

\section{Animals}

Thirty-two adult male albino rats (90-120 days old and 160-250 gm weight) were taken from the Animal House, Moshtohor Faculty of Veterinary Medicine, Benha University. Rats were kept under observation for 1 week before the start of the experiment to acclimatize. They were maintained in a temperature- and humidity-controlled room and given water and food as free access, in which animal experiments were done according to the recommendations and approved protocols for the use of laboratory animals and their proper care.

- Drugs used: Lead nitrate was purchased as powder (AB 228621-100G Sigma-Aldrich, St. Louis, MO, USA).

- Mesenchymal Stem Cell (MSCs) were provided from the unit of stem cell research at the Biochemistry department of the Faculty of Medicine, Cairo University (Cairo, Egypt). MSCs were prepared previously from rat's bone morrow in which isolation and culture of MSCs were done according to the method described by ${ }^{[17]}$.

Identification of MSCs in vitro was done by examination of culture by using an inverted microscope (Leica DM IL LED with camera Leica DFC295; Leica Microsystems CMS GmbH, Wetzlar, Germany) appear as spindle-shaped cells. Flow cytometric analyses were carried out to evaluate the MSCs marker profile, CD90 and CD44 (HPA005785 Sigma-Aldrich, St. Louis, MO, USA) on a Fluorescence Activated Cell Sorter (FACS) flow cytometer (Coulter Epics Elite, Miami, Florida, USA $)^{[18]}$. Then labeling and homing of MSCs with a green fluorescent protein(GFP) in which MSCs were harvested in the fourth passage and labelled with the Green fluorescent protein (AAA27722 Sigma-Aldrich, St. Louis, MO, USA), GFP is a protein that when exposed to light in the blue to the ultraviolet range gives green fluorescence ${ }^{[19]}$. MSCs were centrifuged and washed twice in a serum-free medium. MSCs were transfected with GFP plasmid using lipid-based transfection reagent in which $2 \mu \mathrm{g}$ of plasmid DNA and
$6 \mu \mathrm{L}$ of X-treme GENE HP transfection reagent in $200 \mu \mathrm{L}$ of MESC medium were incubated for 15 minutes at room temperature and added drop-by-drop to freshly seeded MESCs. Cells were cultured normally with a daily change of media. Seventy-two hours after transfection, GFP positive MESCs were selectively taken to new wells for culture. This process was repeated over the next 5 passages till relatively homogenous GFP positive MESCs colonies were established ${ }^{[20,21]}$.

\section{Experimental design}

\section{Rats were divided randomly into three groups}

1. Group I (10 rats) did not receive any treatment and were used as control.

2. Group II (12 rats) (lead toxicity group): a single dose of lead nitrate (LN, $23.3 \mathrm{mg} / \mathrm{kg}$ body weight intravenously) in which $1 \mathrm{~g}$ of lead nitrate powder was dissolved in $2 \mathrm{ml}$ cold water ${ }^{[22]}$.

3. Group III (10 rats) (L N \& MSCs group): a single dose of lead nitrate was taken (LN, $23.3 \mathrm{mg} / \mathrm{kg}$ body weight intravenously). Then after one week of induced lead toxicity a single intravenous dose of $1 \times 106$ MSCs per rat was given and the rats were left for six weeks ${ }^{[23]}$.

\section{Induction of oligospermia}

Oligospermia was induced in group II\& III in which rats were injected with a single dose of lead nitrate (LN, $23.3 \mathrm{mg} / \mathrm{kg}$ body weight) about $1 / 4 \mathrm{LD} 50$ according to the method described by ${ }^{[22 \& 24]}$ in which toxicity was induced one week of lead administration.

\section{Measurement of sperm parameters}

Sperms were collected by diffusion method ${ }^{[25]}$ in which distal end of vas deferens, about $1 \mathrm{~cm}$ were taken from all groups at the end of experiment and then immersed in 3 $\mathrm{mL}$ of Hank's balanced salt solution (HBSS). After $10 \mathrm{~min}$ sperm count was carried out using a hemocytometer ${ }^{[26]}$.

\section{Sexual hormones measurement}

At the end of experiment, animals were anaesthetized by intra-peritoneal injection of $50 \mathrm{mg} / \mathrm{kg}$ pento $\neg$ barbital. Blood was collected from tail vein in which $3 \mathrm{~cm}$ of blood were taken and centrifuged at $3000 \mathrm{rpm} / 20 \mathrm{~min}$ to separate plasma and by solid phase radioimmunoassay (RIA) using components of a commercial kit, quantitative measurement of serum testosterone was carried out (Coat-, Siemens Diagnostics, Los Angeles, USA). Serum sexual hormones including LH and follicle-stimulating hormone (FSH), (DRG ELISA Kit, Germany) were estimated using enzyme- linked immune sorbet assay kits ${ }^{[27]}$.

\section{Histological study}

Two rats of lead toxicity group were sacrificed after one week to asses lead toxicity, while other rats of all groups were sacrificed after seven weeks from starting of the experiment. 
Testis specimens from all groups were fixed in Bouin solution for 4 to 5 hours till it became hard in consistency then proceeded for paraffin block preparation. For the light micro $\neg$ scopic examination, tissue sections of $5 \mu \mathrm{m}$ thickness were stained with haematoxylin and eosin stain to study the structural light micro $\neg$ scopic changes, and Masson's trichrome stain to show collagen fibers ${ }^{[28]}$.

\section{Immunohistochemical method for detection of caspase-3}

Sections of $4 \mu \mathrm{m}$ thickness were used for the immunohistochemical assay of caspace-3 protein (antiapoptotic factor) ${ }^{[29]}$. Polyclonal rabbit antibodies were used for detection of caspase-3. They were purchased from sigma laboratories and kit used the avidin-biotinperoxidase system produced by (AB2302) AB-4 (Novacastra' laboratories Ltd., UK). This kit contained: $6 \mathrm{ml}$ of normal rabbit serum as protein blocking reagent, $0.3 \mathrm{ml}$ avidin, $5 \mathrm{ml}$ of Poly L- lysine solution as a tissue adhesive, $0.3 \mathrm{ml}$ of biotinylated rabbit anti-mouse secondary antibody and $2 \mathrm{ml}$ of hydrogen peroxide with 15 foil wrapped diaminobenzidine (DAB). Paraffin sections were mounted in the slides and incubated at $65^{\circ} \mathrm{c}$ overnight for perfect adhesion. Sections were deparaffinized in xylene, rehydrated in descending grades of alcohol and then immersed in 3\% hydrogen peroxide in methanol for $10 \mathrm{~min}$ to block endogenous peroxidase activity. Then, they were washed in phosphate buffer saline (PBS). 10\% normal serum was applied for $30 \mathrm{~min}$ to decrease non-specific binding. The primary antibody was applied overnight then washed with PBS. Sections were covered with biotinylated secondary anti-mouse antibody for $30 \mathrm{~min}$ and then washed in PBS. Avidin-biotin reagent was applied for 30 min, then washed with PBS. DAB was added for $5 \mathrm{~min}$, as a chromogen and washed with distilled water followed by Mayer's Hematoxylin as a counterstain. Human tonsil (obtained from the pathology department in our institution) served as a positive control according to Manufacturer Company. Negative control slides were prepared by the same steps, except they were incubated with the antibody diluent instead of primary antibody. Positive reaction for caspas-3 appeared in the form of brown nuclear staining ${ }^{[30]}$.

\section{Tracking of Stem Cells}

MSCs labeled with Green Fluorescent Protein (GFP) were observed in testis sections using Fluorescence Microscope (Leica Microsystems CMS GmbH). This was done in the Biochemistry Department, Faculty of Medicine, Cairo University.

\section{Morphometric analysis}

The mean diameter of the seminiferous tubules, seminiferous epithelial height in each group were estimated as ocular micrometer were used to measure the most ten circular seminiferous tubules ${ }^{[31]}$. Mean area $\%$ of collagen fibers content and mean area \% of caspase-3 expression were analyzed using image analyzer (computer system in the morphometric unit in the Histology Department,
Faculty of Medicine, Cairo University) Image- Pro Plus program (version 6.0; Media Cybernetics Inc., Bethesda, Maryland, USA). Ten high-power fields (400X) were measured from sections of all groups and their mean was taken. Statisti $\neg$ cal analyses were carried out using IBM SPSS statistics software for Windows (version 20; IBM Corp., Armonk, New York, USA).

Spermatogenetic activity evaluation was done by using Johnson's score ${ }^{[32]}$. The score was estimated for each testicular slide. In which 100 seminiferous tubules were observed and scored on a scale of 1-10 according to the spermatogenesis level as follow: 10 complete spermatogenesis, 9 minimal impaired spermatogenesis, 8 not more than five spermatozoa per tubule, 7 many early spermatids with no late spermatids, 6 stop of spermatogenesis at the spermatid stage, 5 a lot spermatocytes, 4 minimal spermatocytes; arrest of spermatogenesis at the primary spermatocyte stage, 3 only spermatogonia, 2 no germ cells; Sertoli cells only and 1 no seminiferous epithelial cells; tubular sclerosis.

\section{Statistical analysis}

Data were expressed as mean \pm SD by using one-way ANOVA. $P$ values $<0.05$ were considered to be statistically significant.

\section{RESULTS}

\section{Sperm analysis}

The mean percentage of sperm count and sperm motility for the lead toxicity group were significantly reduced as compared to that of the control group but sperm shape abnormality showed significate increase. In animals treated with MSCs, sperm count and motility were significantly improved. These results are shown in (Table 1 and Histogram 1).

\section{Sexual hormones level}

A significant decrease in sexual hormones level $(0.82 \pm 0.07,5.2 \pm 0.43$ and $3.5 \pm 0.40)$, after treatment with $\mathrm{LN}$ as compared to control rats $(2.2 \pm 0.21,9.3 \pm 0.81$ and $7.2 \pm 0.62)$. The data revealed that MSCs elevate the level of serum of sex hormones and approached control values $(1.9 \pm 0.16,7.8 \pm 0.61$ and $7.1 \pm 0.68)(P<0.05)$ (Histogram 2).

\section{Histological results}

\section{MSCs identification and homing}

Were recognized at 14-days of culture by an inverted microscope as fibroblast shaped cells with some polygonal and rounded cells in between (Figure A1). A fluorescent microscope photo micro graph showing MSCs labeled with green fluorescent dye in vitro (Figure A2). A fluorescent microscope photomicrograph showing MSCs labeled with green fluorescent dye in testis (FigureA3). Image analysis for MSCs characterization showing $95.88 \%$ positivity for CD90 and $97.78 \%$ positivity for CD44 (FigureA4). H\&E 
Control rat's testis showed normal testicular tissue which formed of closely regular seminiferous tubules lined by stratified germinal epithelium. Limited spaces (interstitium) in between the tubules which contain blood vessels and interstitial cells (Figure 1A). Germinal epithelium consists of spermatogonia, spermatocytes, spermatids with spermatozoa in the lumen of seminiferous tubules in control group (Figure1B). Lead toxicity rat's testis (twelve rats) showed nearly totally irregular, shrunken and distorted seminiferous tubules with decrease in the thickness of the testicular epithelium and wide interstitium in between them (Figure 1C). Vacuolated widely separated germ cells with deeply stained nuclei and acidophilic homogenous material in the interstitium with dilated congested blood vessels (Figure 1D).

MSCs treated group revealed that most of the seminiferous tubules appear nearly normal (Figure 1E). While few seminiferous tubules showed mild degeneration and still had a reduced height of their epithelium with separated germ cells with deeply stained nuclei (Figure 1F)

Masson's trichrome of control rat testis showed normal distribution of the collagen fibers in the tunica albuginea, the basal lamina of the seminiferous tubules and the walls of the blood vessel (Figure 2a). The marked increase in the collagen fibers in the testicular capsules, the walls of

A1

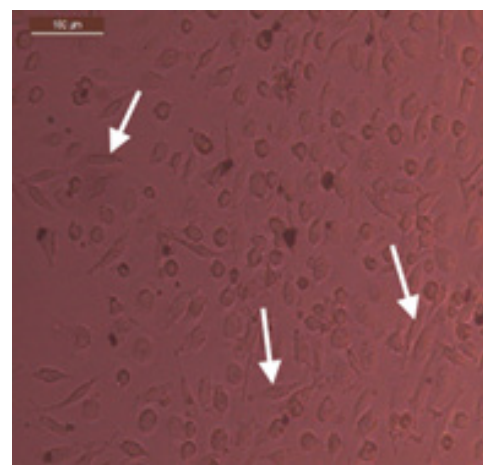

A3

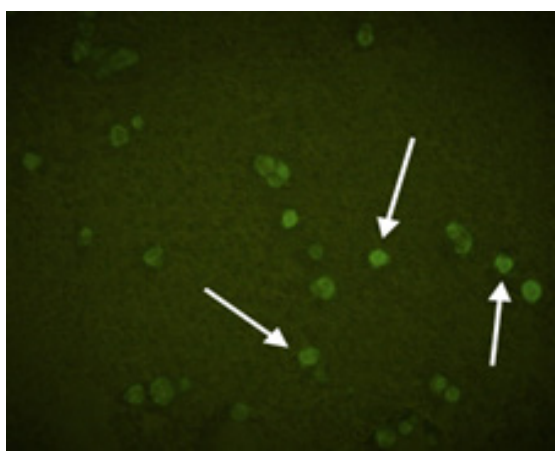

the blood vessels and the basal lamina of the seminiferous tubules observed in LN group (Figure 2b). MSCs treated group revealed that a nearly normal distribution of the collagen fibers as compared to the control group (Figure 2c). Some sections of the MSCs group still showed some increase of collagen fibers (Figure $2 \mathrm{~d}$ ).

\section{Immunohistochemical results}

Control rat's testis showed the negative nuclear reaction of the caspase- 3 in cells lining the seminiferous tubules (in spermatogonia, spermatocytes, spermatids and sertoli cells) as in (Figure 3a). While LN treated group II showed strong positive expression of caspase- 3 in all cells lining the tubules and interstitial cells of Leydig (Figure 3b). MSCs treated group III showed negative expression of caspase-3 was observed in all cell types as in (Figure 3c). In some tubules of MSCs treated rats group weak positive expression of caspase-3 was observed as in (Figure 3d).

\section{Morphometric results}

There was significant difference in lead and MSCs group and lead group in Johnson score, epithelial thickness and seminiferous diameter (Table3). While lead and MSCs group showed there was a significant decrease in the mean area of collagen fibers compared to lead group $(\mathrm{p}<0.05)$ (Table 4). Also, there was a significant decrease in the mean area $\%$ of caspase in lead and MSCs group (Table 5).

A2

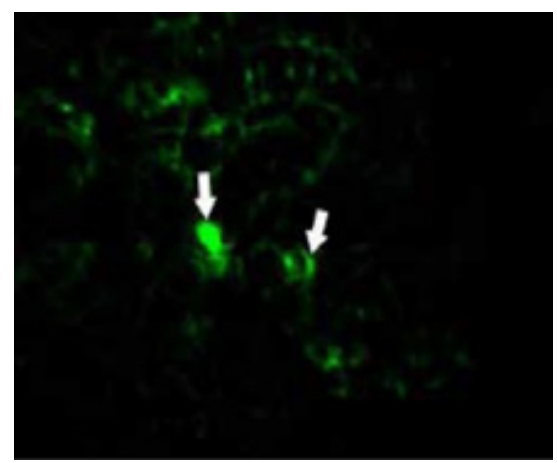

A4

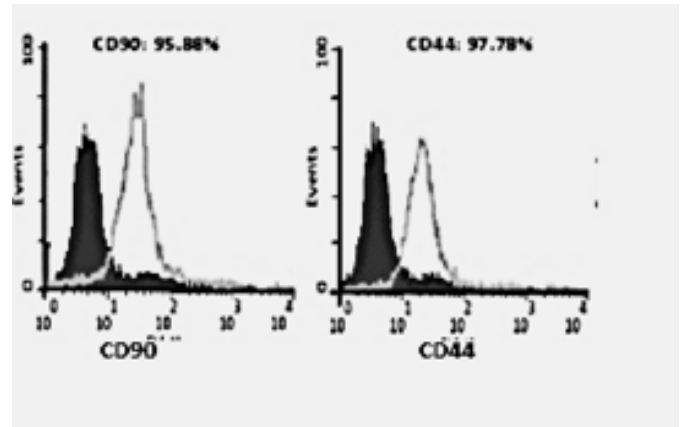

Fig. A: (1) Inverted microscope micrograph of mesenchymal stem cells at 14-day culture. The cultured undifferentiated MSCs are spindle-shaped cells (white $\uparrow)(\times 200)$. A (2) A fluorescent microscope photograph showing MSCs labelled with green fluorescent dyein vitro (arrows) $(\times 1000)$. A $(3)$ A fluorescent microscope photograph showing MSCs labelled with green fluorescent dye in testis(arrows) $(\times 1000$. A (4) image analysis for MSCs characterization showing $95.88 \%$ positivity for CD 90 and $97.78 \%$ positivity for CD 44 


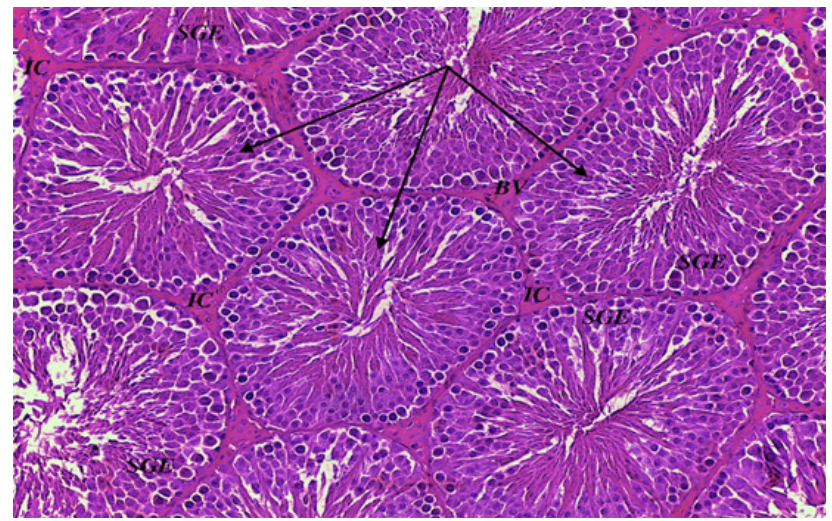

Fig 1A: histological section in testis of adult rat in control group showing crowded regular seminiferous tubules (black arrows) lined by stratified germinal epithelium (SGE) with narrow interstitium in between (IC) with blood vessels (BV). H\&E stain (X 200).

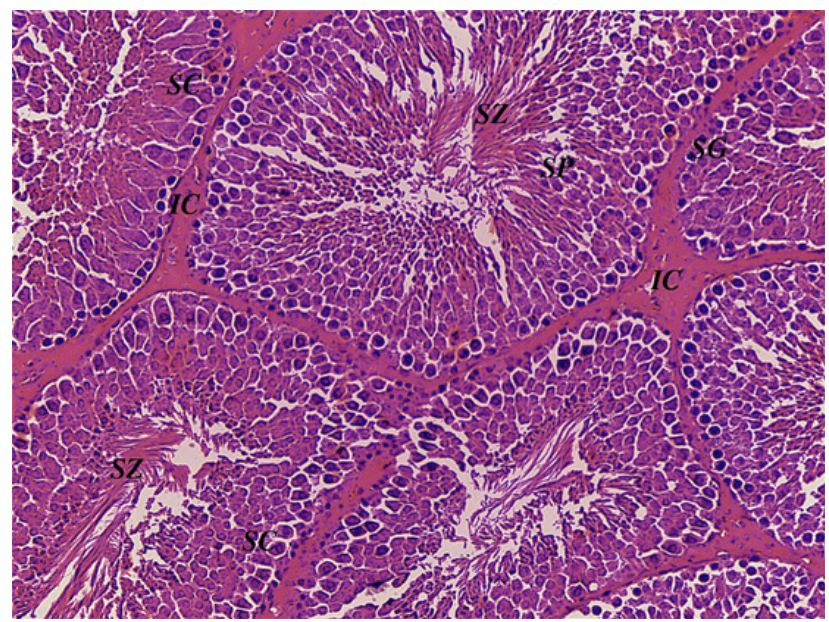

Fig1B: histological section in testis of adult rat in control group showing normal appearance of seminiferous tubules which lined with spermatogonia (SG), spermatocytes (SC), spermatids(SP), with spermatozoa in the lumen (SZ) and narrow interstitium in-between tubules(IC).H\&E stain (X 400).

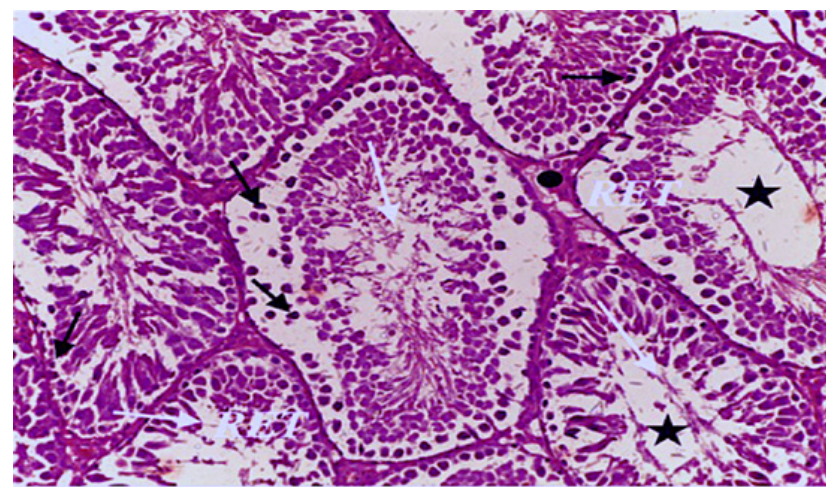

Fig1C: histological section in testis of adult rat in LN toxicity group showing many distorted tubules (white arrows), reduced epithelial thickness (RET), empty lumen (stars), pyknotic nuclei of germinal epithelium (black arrows) and wide interstitial space (circle) H\&E stain (X 200).

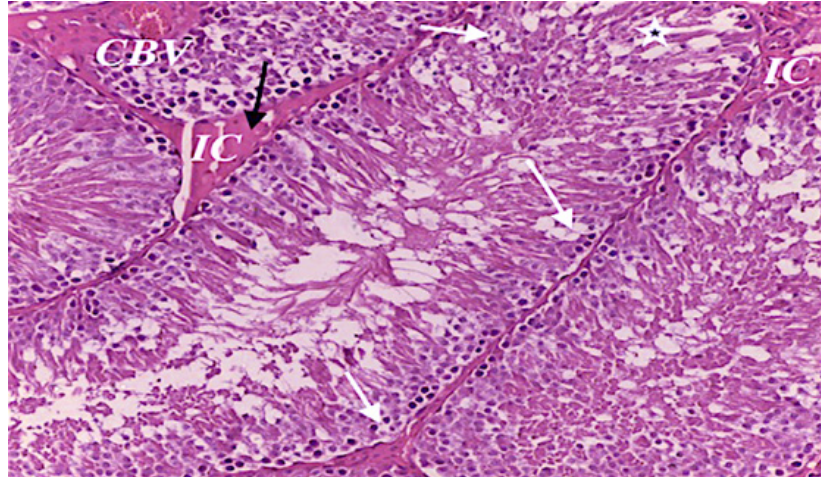

Fig1D: photomicrograph of testis of adult rat in LN toxicity group showing vacuolated cells (white arrows) with wide separation between cells (white star), dilated congested blood vessels (V) and wide interstitial space (IC) with acidophilic homogenous material. H\&E stain (X 400).

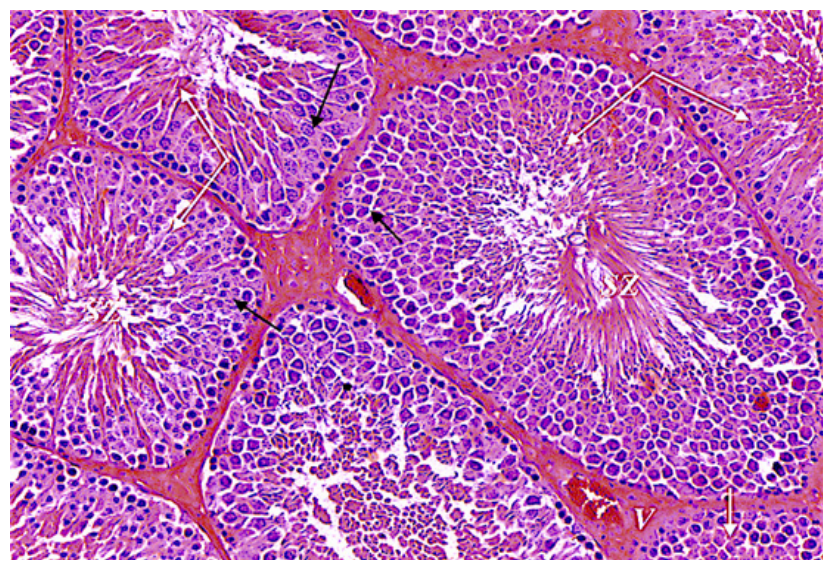

Fig 1E: photomicrograph of testis of adult rat in MSCs treated group showing normal seminiferous tubules (white arrows) with spermatozoa in their lumina (SZ). Evident normal spermatogenic cells (black arrows). Congested blood vessels (V). H\&E stain (X 200).

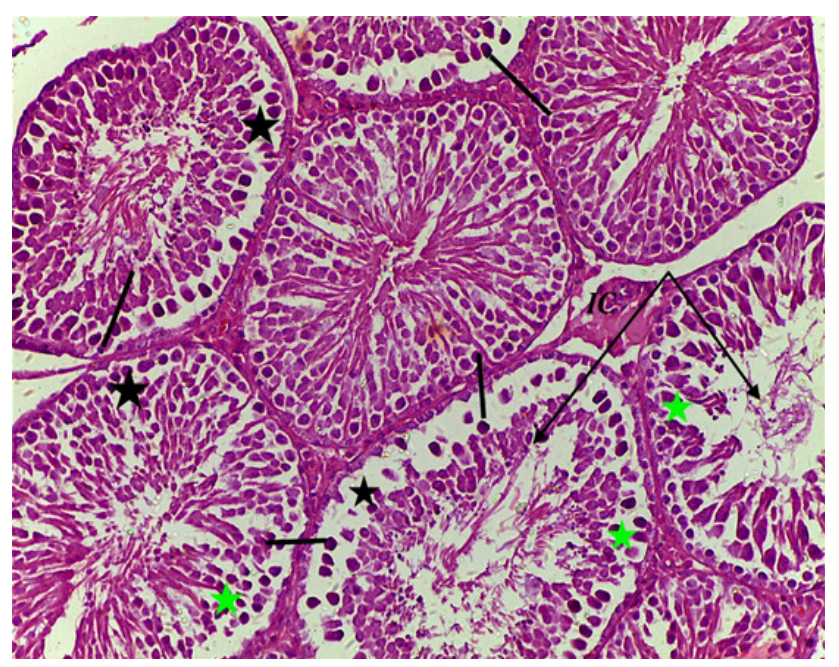

Fig1F: photomicrograph of testis of adult rat in MSCs treated group showing degenerated tubules (black arrows) with reduced epithelial thickness (green stars), separated germ cells (black stars) with pyknotic nuclei (black lines). Wide interstitial space (IC). H\&E stain (X 200). 


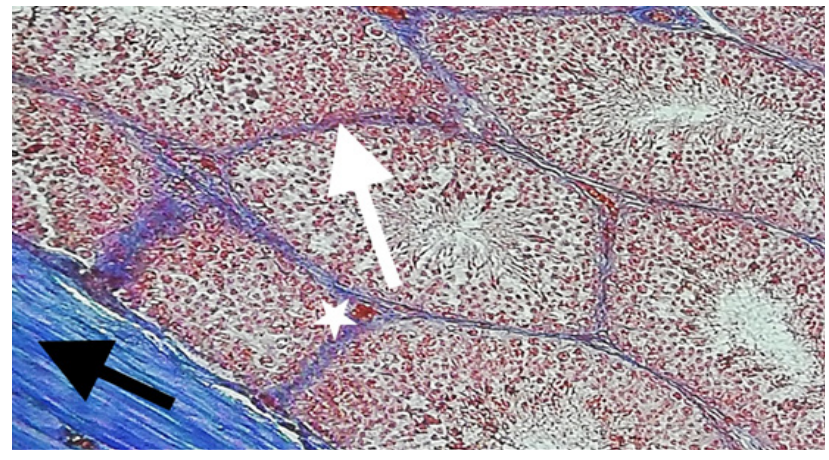

Fig 2a: photomicrograph of testis of adult rat in control group showing normal distribution of collagen fibers in capsule (black arrow), basal lamina of seminiferous tubules (white arrow) and in wall of blood vessels(star). Masson trichrome stain (X 200).

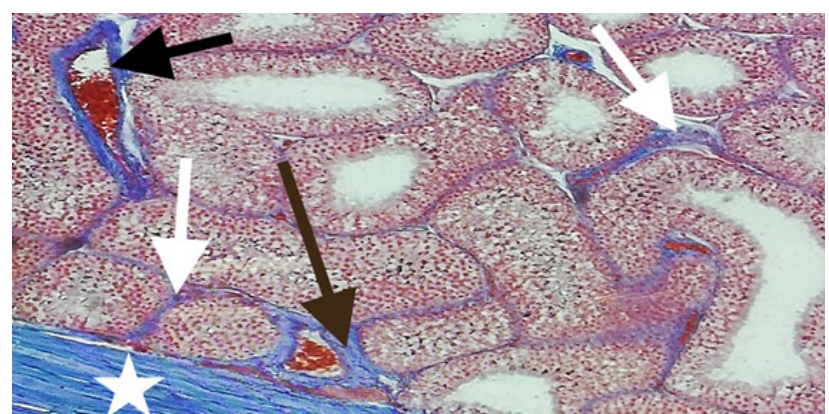

Fig 2b: photomicrograph of testis of adult rat in LN toxicity group showing marked increase of collagen fibers in capsule (star), basal lamina of seminiferous tubules (white arrows) and in wall of blood vessels (black arrows). Masson trichrome stain (X 200)

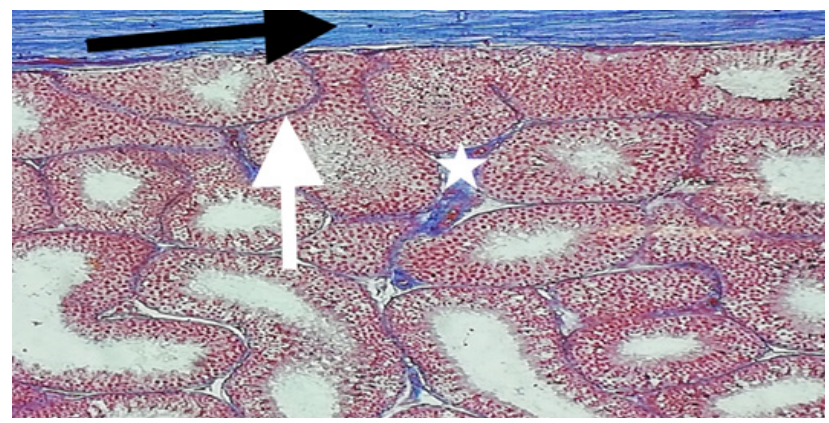

Fig 2c: photomicrograph of testis of adult rat in MSCs treated group showing decreased distribution of collagen fibers in capsule (black arrow), basal lamina of seminiferous tubules (white arrow) and in wall of blood vessels(star). Masson trichrome stain (X 200)

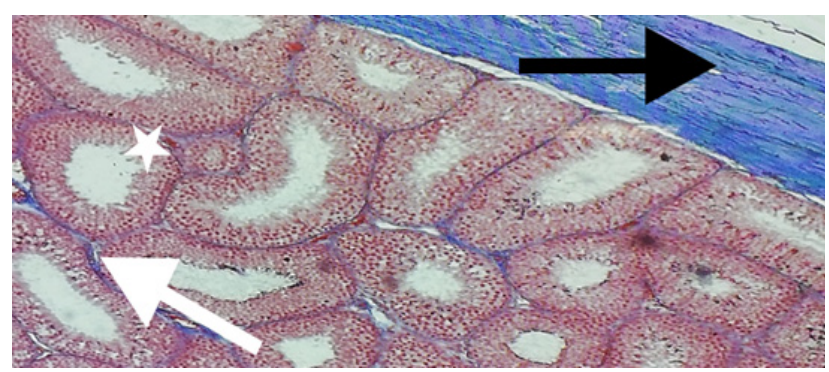

Fig 2d: photomicrograph of testis of adult rat in MSCs treated group showing slight increase in distribution of collagen fibers in capsule (black arrow), basal lamina of seminiferous tubules (white arrow) and in wall of blood vessels(star). Masson trichrome stain (X 200)

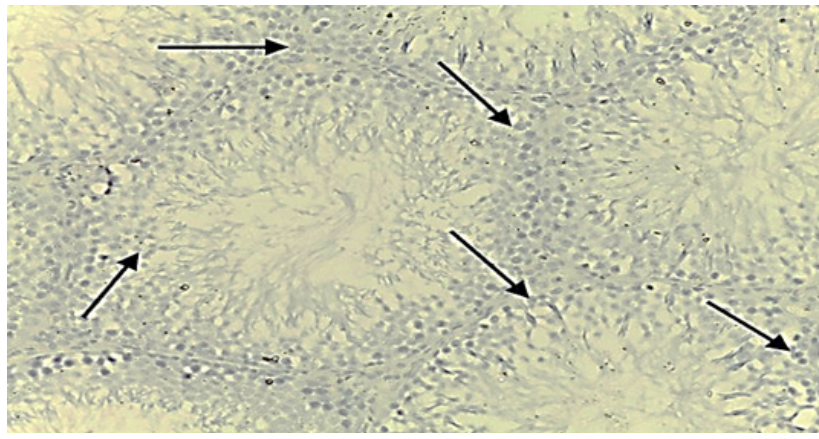

Fig 3a: photomicrograph of testis of adult rat in control group showing negative immunostaining of caspase -3 in all cell types lining the seminiferous tubules and interstitial cells of Leydig (black arrows). caspase -3 immunostaining, $\times 200$

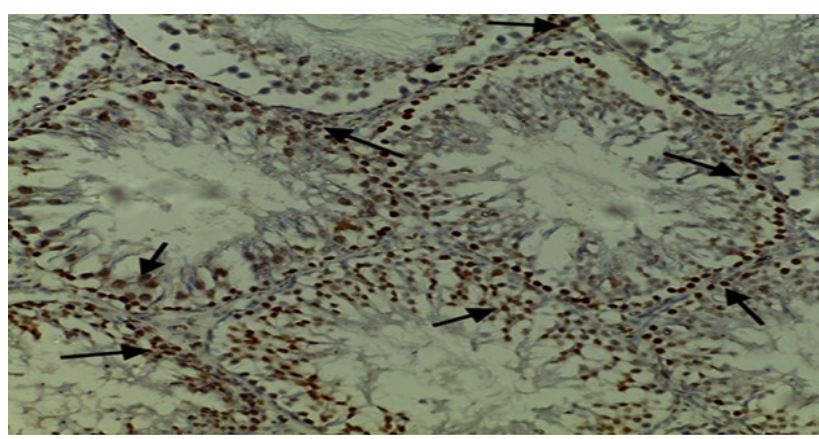

Fig 3b: photomicrograph of testis of adult rat in LN toxicity group showing strong positive immunostaining of caspase -3 in all cell types lining the seminiferous tubules and interstitial cells of Leydig (black arrows). caspase -3 immunostaining, $\times 200$.

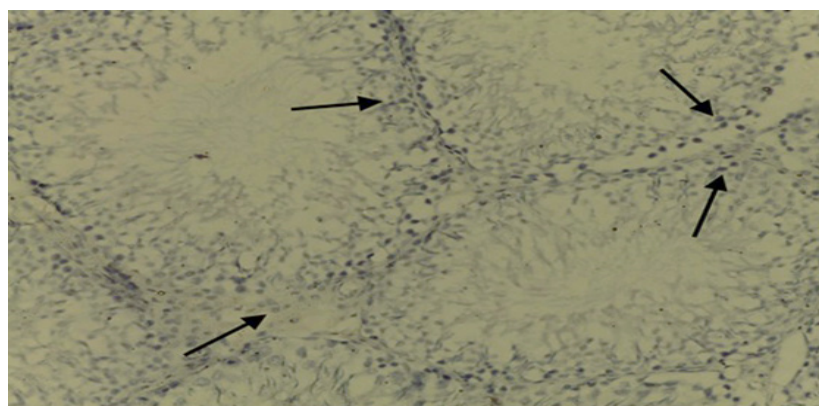

Fig 3c: photomicrograph of testis of adult rat in MSCs treated group showing negative immunostaining of caspase -3 in all cell types lining the seminiferous tubules and interstitial cells of Leydig (black arrows). caspase -3 immunostaining, $\times 200$.

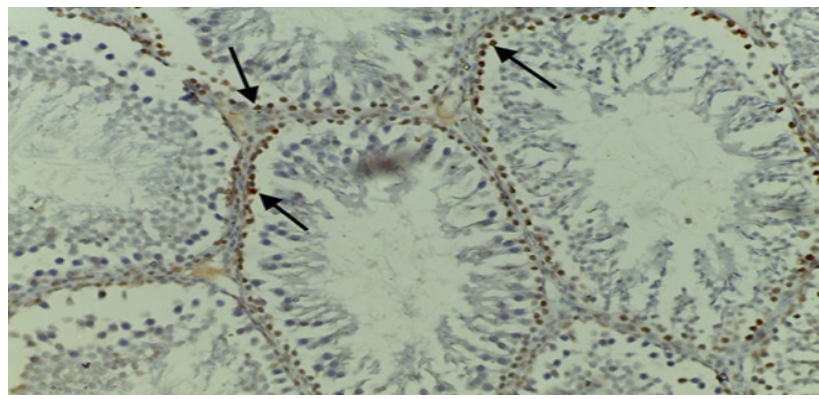

Fig 3d: photomicrograph of testis of adult rat in MSCs treated group showing weak positive immunostaining of caspase -3 in cell lining few seminiferous tubules and interstitial cells of Leydig (black arrows). caspase -3 immunostaining, $\times 200$ 
Table 1: sperm analysis in different groups

\begin{tabular}{|c|c|c|c|}
\hline Parameters $\quad$ Groups & Control & $\mathrm{LN}$ & $\mathrm{LN}+\mathrm{MSCs}$ \\
\hline Sperm count $\left(10^{6} / \mathrm{ml}\right)$ & $100.5 \pm 0.71$ & $51.45 \pm 0.21^{\mathrm{a}}$ & $96.65 \pm 1.074^{b}$ \\
\hline Sperm motility $\%$ & $97.83 \pm 2.054$ & $42.16 \pm 0.4^{\mathrm{a}}$ & $86.48 \pm 0.26^{\mathrm{b}}$ \\
\hline Abnormal sperm (\%) & $9.66 \pm 1.082$ & $55.87 \pm 11.051^{\mathrm{a}}$ & $23.06 \pm 0.49^{b}$ \\
\hline Sperm morphology $\%$ & $92.3 \pm 0.47$ & $45.3 \pm 0.72^{\mathrm{a}}$ & $80.97 \pm .0 .62^{\mathrm{b}}$ \\
\hline
\end{tabular}

-LN: lead nitrate and MSCs: mesenchymal stem cells.

- a is significant as compared to control group, while b is related to lead group ( $P$ values $<0.05$ were considered to be statistically significant).

Table 2: means $\pm \mathrm{SE}$ of sexual hormones in all groups

\begin{tabular}{|c|c|c|c|}
\hline Parameters $\quad$ Groups & Control & LN & $\mathrm{LN}+\mathrm{MSCs}$ \\
\hline LH (ng/ml) & $2.2 \pm 0.21$ & $0.82 \pm 0.07^{\mathrm{a}}$ & $1.9 \pm 0.16^{\mathrm{b}}$ \\
\hline FSH (ng/ml) & $9.3 \pm 0.81$ & $5.2 \pm 0.43^{\mathrm{a}}$ & $7.8 \pm 0.61^{\mathrm{b}}$ \\
\hline Testosterone (ng/ml) & $7.2 \pm 0.62$ & $3.5 \pm 0.40^{\mathrm{a}}$ & $7.1 \pm 0.68^{\mathrm{b}}$ \\
\hline
\end{tabular}

a versus control group, b versus $\mathrm{LN},{ }^{*} p<0.01$ is considered significant

Table 3: The Johnson score, epithelial thickness and seminiferous diameter in all groups

\begin{tabular}{lccc}
\hline Parameters & $\begin{array}{c}\text { Groups } \\
\text { Control }\end{array}$ & $\begin{array}{c}\text { Mean value } \\
\text { LN }\end{array}$ & $\begin{array}{c}\text { Mean value } \\
\text { LN +MSCs }\end{array}$ \\
\hline Johnson score & $9.67 \pm 0.32$ & $5.67 \pm 0.12^{\mathrm{a}}$ & $9.33 \pm 0.52^{\mathrm{b}}$ \\
Epithelial thickness & $106.42 \pm 3.35$ & $82.62 \pm 1.77^{\mathrm{a}}$ & $99.63 \pm 1.04^{\mathrm{b}}$ \\
Seminiferous diameter & $357.83 \pm 4.58$ & $309.57 \pm 5.60^{\mathrm{a}}$ & $338.15 \pm 8.72^{\mathrm{b}}$ \\
\hline
\end{tabular}

T a versus control group, b versus $\mathrm{LN}, * p<0.01$ is considered significant

Table 4: The mean area $\%$ and SD of collagen fibers accumulation between groups.

\begin{tabular}{|c|c|c|c|}
\hline Parameters $\quad$ Groups & Control & $\mathrm{LN}$ & $\mathrm{LN}+\mathrm{MSCs}$ \\
\hline Mean area $\%$ & $0.15 \%$ & $25.28 \%$ & $1.65 \%$ \\
\hline $\mathrm{SD} \pm$ & 0.01 & $0.06 \mathrm{~s}$ & $0.02 \mathrm{~s}$ \\
\hline Pvalue & & 0.050 & 0.033 \\
\hline
\end{tabular}

$\mathrm{S}=$ Significant at $P<0.05$ and $\mathrm{SD}=$ standard deviation

Table 5: The mean area \% of caspase expression and SD in examined groups

\begin{tabular}{|c|c|c|c|}
\hline Parameters & Control & LN & $\mathrm{LN}+\mathrm{MSCs}$ \\
\hline Mean area \% & $0.25 \%$ & $1.86 \%$ & $0.39 \%$ \\
\hline $\mathrm{SD} \pm$ & 0.01 & $0.12 \mathrm{~s}$ & $0.210 \mathrm{~s}$ \\
\hline Pvalue & & 0.050 & 0.033 \\
\hline
\end{tabular}

$\mathrm{S}=$ Significant at $P<0.05$ and $\mathrm{SD}=$ standard deviation

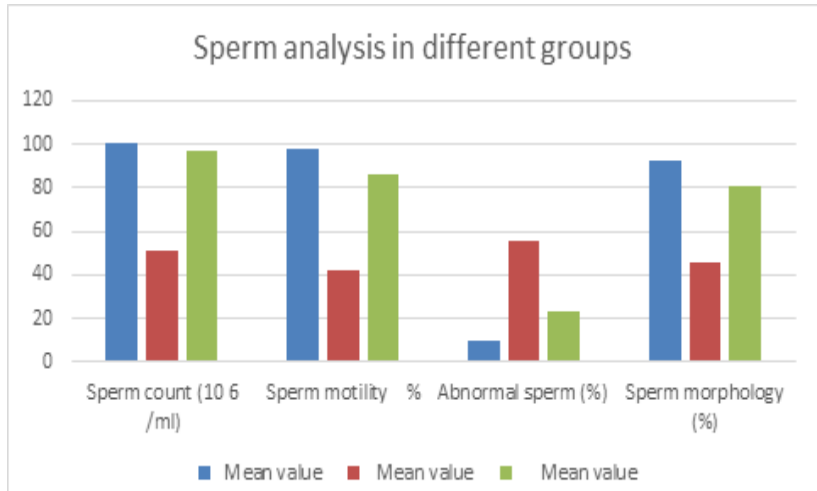

Histogram 1: The Johnson score, the epithelial thickness and seminiferous diameter in all groups

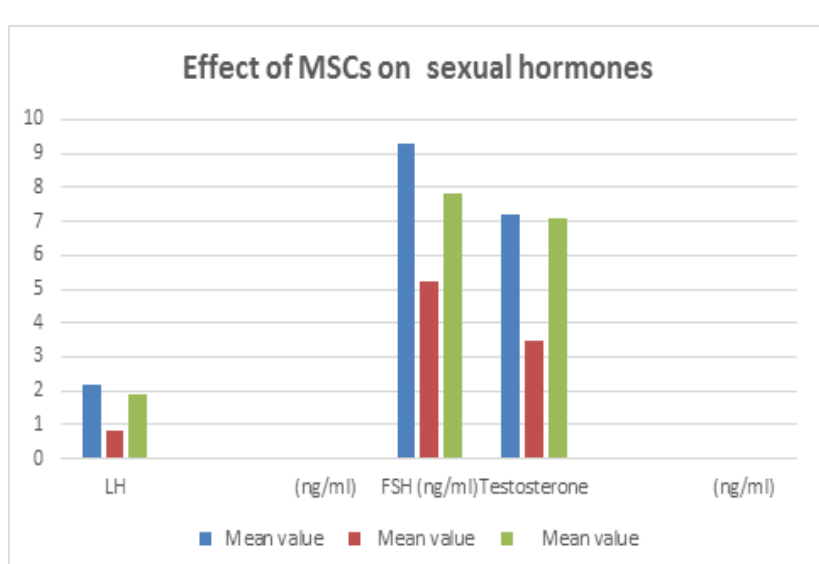

Histogram 2: The mean area \% and SD of collagen fibers accumulation between groups

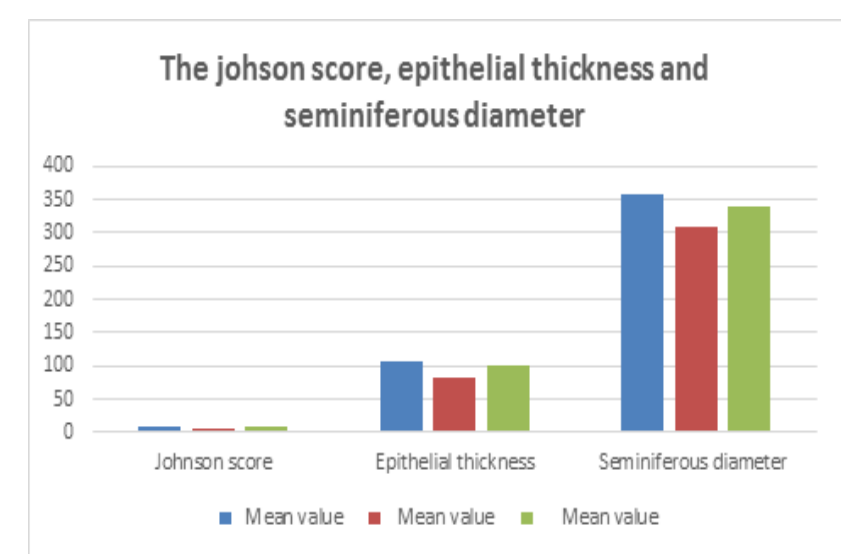

Histogram 3: The mean area \% of caspase expression and SD in examined groups 


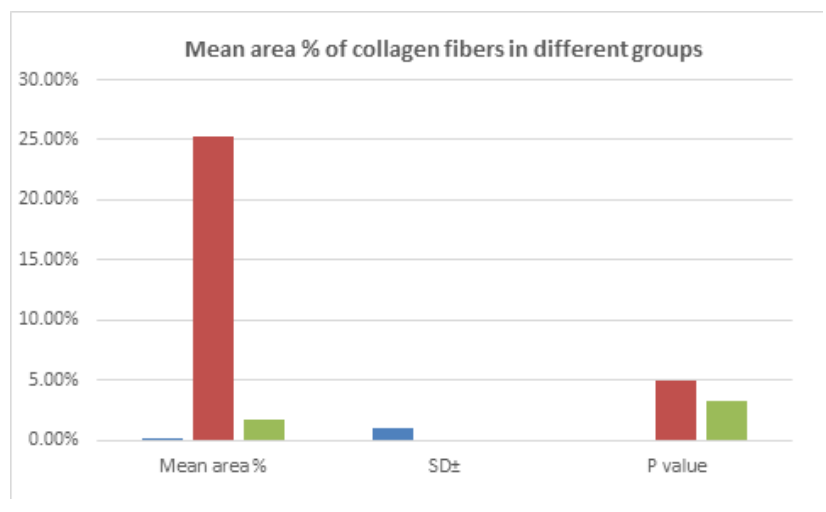

Histogram 4: The mean area $\%$ and SD of collagen fibers accumulation between groups

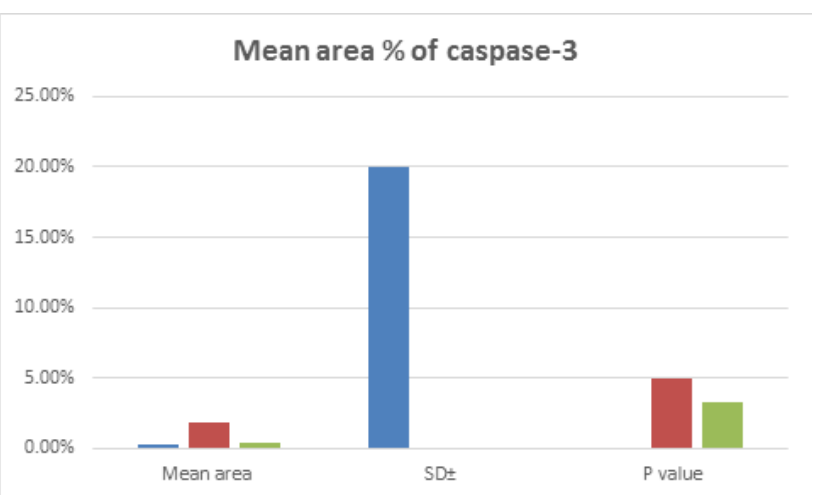

Histogram 5: The mean area \% of caspase expression and SD in examined groups

\section{DISCUSSION}

Lead as a Heavy metal is considered as severely toxic heavy metal. It has serious occupational hazards all over the world ${ }^{[33]}$.

Heavy metals have adverse side effects on the male reproductive system, affecting sperm motility, sperm count, morphology ${ }^{[34]}$ and spermatogenesis ${ }^{[35]}$.

Our study was done to check the effect of MSCs on experimentally induced oligospermia.

In the present study administration of lead nitrate causes, significant decrease in sperm count and their motility as compared to the control group with abnormal sperms. As lead has the ability to pass through blood-testis barrier and lead to impairment of the spermatogenesis by DNA damage of spermatogonia and spermatocytes ${ }^{[36]}$.

The abnormal sperm characteristics associated with lead administration compared to the control group may be due to the decrease in testosterone level which is seen in our study. The testosterone hormone is essential for spermatogenesis, normal development of sperms and normal structural physiology of seminiferous tubules ${ }^{[37]}$.

The significant decrease in plasma testosterone concentration of rats with lead toxicity may be due to a decrease in the expression of enzymes which are needed for the hormonal synthesis of steroids like testosterone and luteinizing hormone (LH). This decrease in the testosterone and LH level was due to many physiological mechanisms. The decrease in the number of LH binding sites in Leydig cells ${ }^{[38]}$. Some authors showed that the physiological mechanism is the reduction in plasma level of prolactin because prolactin has a direct role in LH binding sites in rat's testes ${ }^{[39]}$. All the above factors could have many effects on spermatogenesis and Leydig cells function and which are considered the targets of lead molecules ${ }^{[40]}$.

The histological results of testis of rats with lead toxicity showed degeneration of the seminiferous tubules and alteration of spermatogenesis. There were distorted seminiferous tubules with widening of the interstitium in-between and marked decrease in the thickness of the germinal epithelium, with many deeply stained nuclei. Seminiferous tubules showed the absence of mature sperms in the lumen and congestion of testis blood vessels. Nearly Similar changes with the presence of immature cells within the seminiferous tubular lumen were seen in rats under the effect of lead acetate ${ }^{[4]}$. Above results also agreed with those reported by some authors ${ }^{[42]}$ in which they explained the reduction of sperms which occurred in rats with leadtoxicity was mainly due to an abnormal change in the different stages of spermatogenesis and decrease numbers of spermatids which lead to loss of spermatozoa in the seminiferous lumen.

The spermatids were affected more when compared with other germ cells and absences of sperms in the most of seminiferous tubules were observed by ${ }^{[43]}$.

On the other hand, separation of cells from the basal membrane of the seminiferous tubules may be due to cellular degeneration ${ }^{[41]}$.

It has been documented that the lead has the ability to cross the blood-testis barrier resulting in detachment of Sertoli and germ cells in vitro from the basal lamina ${ }^{[44]}$. The mechanism of damage is by inducing lipid peroxidation, oxidative stress, and production of reactive oxygen species which may damage the biological membranes in the testes with degeneration of the spermatogenic and inhibit the process of androgenesis by Leydig cells in tes $\neg$ tis tissue ${ }^{[45]}$.

Lead nitrate has been shown to accumulate in the testis resulting in the reduction of spermatogenic cells as result of oxidative damage ${ }^{[46]}$

Many studies have provided that the metals are able to interact with nuclear DNA leading to oxidative damaged cells $^{[47]}$.

Sperm DNA damage is an indicator of infertility of male and this may be affected by cell apoptosis and oxidative stress $^{[48]}$.

In the present study, the rats treated with MSCs showed a significant increase level of sperm count and their motility, and decrease the percentage of abnormal sperms. Also, there is an elevation in testosterone level, in 
comparison to that group treated by lead. So, MSCs may have a potential chance of treating male oligospermia and testosterone deficiency. It could also be suspected that the improving effects of MSCs can be due to their ability to differentiate into male germ cells ${ }^{[49]}$.

Many authors proved that MSCs have the ability to differentiate into both spermatogenic cells and steroidogenic cells, such as Leydig cells, both in vitro and in $v i v o^{[50]}$. Immunohistochemical detection of caspas-3 is one method for identification of apoptotic cells.

Many studies explain that the MSCs can protect the testis from oxidative damage and apoptotic which done by lead toxicity as MSCs produce stem cell factors (SCF) that pass to the spermatogenic cells and Sertoli cell to enhance the synthesis of their DNA and so MSCs can improve the histopathological changes in the testis ${ }^{[51]}$ and this was in agreement with our results as there was significant decrease in casapase-3 as antiapoptic marker with MSCs treated group. study has found that activation of apoptosis machinery in germ cell involves the Fas/Fas ligand system $^{[52]}$. Fas ligand is produced by Sertoli cells and Fas receptor is localized on spermatocytes and spermatids, as well as Sertoli cells and SCF has antiapoptotic effects through inhibit Fas ligand ${ }^{[53]}$.

Other researcher reported that the MSCs might have the ability to improve spermatogenesis by the ability of MSCs to differentiate into sperm or by the maintenance of the spermatogonial stem cells ${ }^{[54]}$.

\section{CONCLUSIONS}

The present study suggests that MSCs can improve the male oligospermia caused by lead toxicity. MSCs reestablishment of spermatogenesis through differentiation into sperms or by their anti-apoptotic effect. MSCs have a very promising approach in regenerative medicine as $\mathrm{MSCs} / \mathrm{BM}$ are capable of differentiating into germ cells and Leydig cells in the testis.

\section{ACKNOWLEDGEMENTS}

The authors thank Dr. Mohamed Farid, professor of toxicology in Benha faculty of Medicine, Egypt, for calculating the dose of lead nitrate and the technicians in the Department of pathology, Oncology Institute in Cairo Egypt for their help throughout this work.

\section{CONFLICTS OF INTEREST}

There are no conflicts of interest.

\section{REFERENCES}

1. Agarwal A, Mulgund A, Hamada A, Chyatte MR. A unique view on male infertility around the globe. Reprod Biol Endocrinol. 2015.26;13:37.

2. Filipe T, Lira NP, Vu BB, Philip S, LiM . Spermatogenesis in humans and its affecting factors. Seminars in Cell \& Developmental Biology.2016 ; 59: 10-26.
3. Patra R C, Rautray AK and Swarup D. Oxidative stress in lead and cadmium toxicity and its amelioration. Vet. Med. Inter. Article ID 2011; 457327: 1-9.

4. Ab Latif W, Anjum A Jawed A U. Lead toxicity: a review. Interdiscip Toxicol. 2015; 8(2): 55-64.

5. Kakkar P and Jaffery FN: Biological markers for metal toxicity. Environ Toxicol Pharmacol. j.etap . 2005; 19:335-349.

6. Vigeh M and Smith DR, Hsu PC. How does lead induce male infertility? Iran J Reprod Med. 2011;9(1):1-8.

7. Hanan L A, Zainab M A, Israa F J. Environmental Lead Exposure and Male Infertility. Journal of Dental and Medical Sciences. 2016;15: PP 49-54.

8. Wani AL, Ara A and Usmani JA. Lead toxicity: a review. Interdiscip Toxicol. 2015;8(2):55-64.

9. Flora G, Gupta D and Tiwari A. Toxicity of lead: A review with recent updates. Interdiscip Toxicol. 2012;5(2):47-58.

10. Das KK and Saha S. L-ascorbic acid and alpha tocopherol supplementation and antioxidant status in nickel- or lead-exposed rat brain tissue. J Basic Clin Physiol Pharmacol.2010; 21: 325-346.

11. Faruk EM, El-desoky RE, Al-Shazly AM and Taha NM. Does Exosomes Derived Bone Marrow Mesenchymal Stem Cells Restore Ovarian Function by Promoting Stem Cell Survival on Experimentally Induced Polycystic Ovary in Adult Female Albino Rats? (Histological and Immunohistochemical Study). Stem Cell Res Ther.2018; 8: 442. doi: 10.4172/21577633.1000442 .

12. François M, Copland IB, Yuan S, Romieu-Mourez R, Waller EK, Galipeau J. "Cryopreserved mesenchymal stromal cells display impaired immunosuppressive properties as a result of heat-shock response and impaired interferon- $\gamma$ licensing". Cytotherapy. 2012;14 (2): 147-52.

13. Zhang Y, Khan D, Delling J and Tobiasch E. Mechanisms Underlying the Osteo- and AdipoDifferentiation of Human Mesenchymal Stem Cells. Sci World J. 2012 ;3(2):23-43.

14. Abd Allah S H, Pasha H F, Abdelrahman A A and Mazen N F. Molecular effect of human umbilical cord blood CD34-positive andCD34-negative stem cells and their conjugate in azoospermic mice. Molecular and Cellular Biochemistry.2017;428, 179-191.

15. Aghamir S M, Salavati A, Yousefie R, Tootian Z, Ghazaleh N, Jamali, M and Azimi P. Does bone marrow-derived mesenchymal stemcell transfusion prevent antisperm antibody production after traumatictestis rupture? Urology.2014;84,82-86. 
16. Amidi, F, Ataie Nejad N, Agha Hoseini M, Nayernia K, Mazaheri Z, Yamini N and Saeednia S. In vitro differentiation process ofhuman Wharton's jelly mesenchymal stem cells to male germ cells in thepresence of gonadal and nongonadal conditioned media with retinoicacid.In Vitro Cellular and Developmental Biology Animal DevelopmentalBiology.2015;51, 1093-1101.

17. Augello A, Kurth T B and Bari C. Mesenchymal stem cells: Aperspective from in vitro cultures to in vivo migration and niches.European Cells \& Materials.2010; 20, e33.

18. Azizollahi S, Aflatoonian R, Sadighi Gilani M A, Behnam B, TajikN, Asghari-Jafarabadi M and Koruji M. Alteration of spermato-genesis following spermatogonial stemc ells transplantation intesticular torsion-detorsion mice.Journal of Assisted Reproduction and Genetics.2016; 33, 771-781.

19. Chudakov DM, Matz MV, Lukyanov S and Lukyanov KA. "Fluorescent proteins and their applications in imaging living cells and tissues". Physiological Reviews. 2010; 90 (3): 1103-63.

20. Omar FR,Amin NMAand ElsherifHA. Role of adiposederived stem cellsin restoring ovarian structure of adult albino rats with chemotherapy-induced ovarian failure: a histological and immunohistochemical study. J Carcinog Mutagen. 2016; 7: 1-12.

21. Soleimani M and Nadri S. A protocol for isolation and culture of mesenchymal stem cells from mouse bone marrow. Nat Protoc. 2009; 4: 102-106.

22. Lewis R J.Sr.(ed)Sax,s Dngerous Properties of Industrial $\mathrm{M}$ aterials. $11^{\text {th }}$ edation. Wiley-Interscience, Willy \& S o nus, In s Hoboken,NJ.2004;P.2217.

23. Zahra P, Leili A, Morteza M and Bahman Y.Current approaches for the treatment of male infertility with stem cell therapy. J of celluler physiology.2019; 233 (10):1104-32.

24. O, Neil M J (ed). The Merk Index - An Encyclopedia of Chemiacals Drug, and Biologicals. Whitehouse Station. NJ:Merk and Co.,Inc.,2006.,p.938.

25. Seed J, Chapin RE, Clegg ED, Dostal LA, Foote RH and Hurtt E. Methods for assessing sperm motility, morphology and counts in the rat, rabbit \& dog: a consensus report. ILSI Risk Science Institute Expert Working Group on Sperm Evaluation. Reprod Toxicol. 1996; 10:237-244. [PubMed]).

26. Flora SJS, Pachauri V and Saxena G. Arsenic, cadmium and lead. Reproductive and Developmental Toxicology.2011; (Academic Press) pp 415-438.

27. Richards JB, Hallford DM and Duff G: Serum luteinizing hormone, testosterone, and thyroxine and growth responses of ram lambs fed locoweed (Oxytropis sericea) and treated with vitamin E/ selenium. Theriogenology. 1999; 52: 1055-1066.

28. Bancroft JD and Layton C. The hematoxylin and eosin, connective and mesenchymal tissues with their stains. In: Suvarna SK, Layton C, Bancroft JD (eds). Bancroft's Theory and practice of histological techniques (7thedn).2013; Churchill Livingstone,Philadelphia, pp: 173-212).

29. Ummanni R, Lehnigk U, Zimmermann U, Woenckhaus $\mathrm{C}$, Walther $\mathrm{R}$ and Giebel J. Immunohistochemical expression of caspase- 1 and -9 , uncleaved caspase-3 and -6 , cleaved caspase- 3 and -6 as well as Bcl-2 in benign epithelium and cancer of the prostate. Exp Ther Med. 2010;1(1):47-52.

30. Xia L and Xue XZ. Immunohistochemical study of NF- $\kappa \mathrm{B}$ p65, c-IAP2 and caspase-3 expression in cervical cancer. Oncol Lett. 2012;3(4):839-844.

31. Sharpe R M. Sperm counts and fertility in men: A rocky road ahead.EMBO Reports.2012;13, 398-403.

32. Celik O, Kutlu O, Tekcan M, Celik-Ozenci C, T and Koksal I. Role of TNF-related apoptosis-inducing ligand (TRAIL) in the pathogenesis of varicoceleinduced testicular dysfunction. Asian J Androl 2013; 5: 269-274.

33. Ibrahim NM, Eweis EA, El-Beltagi HS and Yasmin E. Effect of lead acetate toxicity on experimental male albino rat. Asian Pac J Trop Biomed. 2012; 2:41-46.

34. Meeker JD, Rossano MG, Protas B, Diamond MP, Puscheck E, et al. Cadmium, lead, and other metals in relation to semen quality: human evidence for molybdenum as a male reproductive toxicant. Environ Health Perspect.2008; 116: 1473-1479.

35. Sharma V, Sharma A and Kansal L. The eff ect of oral administration of Allium sativum extracts on lead nitrate induced toxicity in male mice. Fd Chem Toxicol.2010; 48: 928-936.

36. Ahmed YF, Karima GH, Mahmoud AA, Mona F and Abo-Zeid A: Some studies on the toxic effects of prolonged lead exposure in male rabbits: chromosomal and testicular alterations. Global Veterinaria 2012; 8:360-366.

37. Falana BA and Oyeyipo IP: Selenium and zinc attenuate lead-induced reproductive toxicity in male sprague-dawley rats. Res J Med Sci 2012; 6:66-70.

38. El-Sayed YS and El-Neweshy MS. Impact of lead toxicity on male rat reproduction at hormonal and histopathological levels. Toxicol Lett, 2010; 92: 765-774.

39. Hamadouche AN, Slimani M, Merad-Boudia B and Zaoui C. Reproductive toxicity of lead acetate in adult male rats. Am J Sci Res 2009; 3: 38-50. 
40. Mendiola J, Moreno JM, Vergara-Jurez N, MartnezGarca MJ, Garca-Snchez A, Elvira-Rendueles B, Moreno-Grau S, L, pez- Espn J, Bernabeu R and Torres-Cantero AM: Relationships between heavy metal concentrations in three different body fluids and male reproductive parameters: a pilot study.Environ Health 2011; 10:6.

41. Sainath SB, Meena R, Supriya C, Reddy KP and Reddy PS. Protective role of Centella asiatica on leadinduced oxidative stress and suppressed reproductive health in male rats. Environ Toxicol Pharmacol. 2011;32: 146-154.

42. Jangid AP, John PJ, Yadav D, Mishra S and Sharma P. Impact of chronic lead exposure on selected biological markers. Indian J Clin Biochem .2012;27: 83-89.

43. Suradkar SG, Vihol PD, Patel JH, Ghodasara DJ, Joshi $\mathrm{BP}$, et al. Patho-morphological changes in tissues of Wistar rats by exposure of Lead acetate. Veterinary World. 2010; 3: 82-84.

44. Wu HM, Lin-Tan DT, Wang ML, et al. Lead level in seminal plasma may affect semen quality for men without occupational exposure to lead. Reprod Biol Endocrinol. 2012;10:91. doi:10.1186/1477-782710-91

45. Awadalla NJ, El-Helaly M, Gouida M, Mandour R and Mansour M. Sperm Chromatin Structure, Semen Quality and Lead in Blood and Seminal Fluid of Infertile Men. Int. J. of Occup. And Environ Med 2011;2(1): 27-36.

46. Dirican EK and KalenderY.D. Induced testicular toxicity in male rats and the protective role of vitamins C and E. Exp Toxicol Pathol.2012; 64: 821-830.

47. Saleh MA, Taha EA, Ismail SA, Gaber HD, Morsi HA and Ghandour NM. Lead and Cadmium assay in Serum and Semen of Infertile Men attending Andrology clinic in Assiut University Hospital (Rural versus Urban). J Environ Sci, Toxicol Food Tech 2013;2(4): 38-45.
48. Kansal LE, Sharma AR and Lodi H: Remedial effect of coriandrum sativum (coriander) extracts on lead induced oxidative damage in soft tissues of swiss albino mice. Int J Pharm Pharm Sci .2012; 4:729-736.

49. Xie L, Lin L., Tang Q, Li W, Huang T., Huo X and Ma L Sertoli cell-mediated differentiation of male germ cell-like cells from humanumbilical cord Wharton's jelly-derived mesenchymal stem cells in an in vitro co-culture system.European Journal of Medical Research.2015;20,9.

50. Zhang P, Chen X, Zheng Y, et al. Long-term propagation of porcine undifferentiated spermatogonia. Stem Cells Dev 2017; 26:1121-1131.

51. de Michele F, Poels J, Weerens L, et al. Preserved seminiferous tubule integrity with spermatogonial survival and induction of Sertoli and Leydig cell maturation after long-term organotypic culture of prepubertal human testicular tissue. Hum Reprod 2016 ; 32:32-45.

52. Figueira MI, Correia S, Vaz CV, Cardoso HJ, Gomes IM, Marques R, Maia CJ, Socorro S Estrogens down-regulate the stem cell factor $(\mathrm{SCF}) / \mathrm{c}-\mathrm{KIT}$ system in prostate cells: Evidence of antiproliferative and proapoptotic effects. Biochem Pharmacol. 2016;99:73-87. doi: 10.1016/j.bcp.2015.11.016. Epub 2015 Nov 23.

53. The stem cell factor (SCF)/c-KIT system in carcinogenesis of reproductive tissues: What does the hormonal regulation tell us? Figueira MI, Cardoso HJ, Correia S, Maia CJ, Socorro S.Cancer Lett. 2017; 405:10-21. Epub 2017 Jul 24.

54. de Michele F, Vermeulen M, Wyns, C. Fertility restoration with spermatogonial stem cells. Current Opinion in Endocrinology \& Diabetes and Obesity, Volume 24, Number 6, December 2017; (8). 424-431. 


\section{الملخص العربى}

التغيرات الهيكلية المجهرية المستجيبة لحقن الخلايا الجذعية

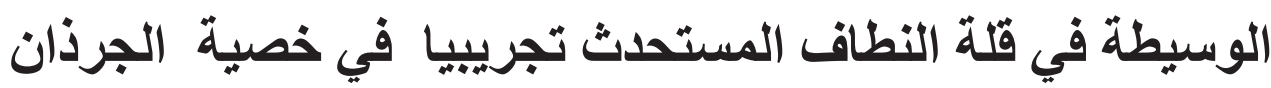
البالغة (دراسة هستولوجية و هستوكيميائية مناعية)

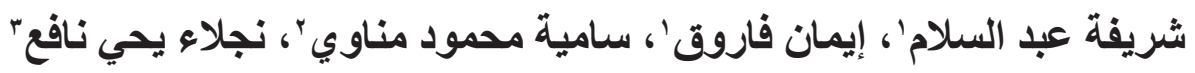

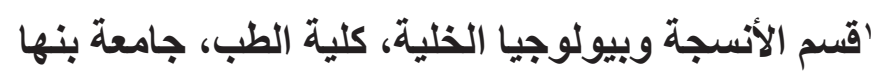

بقسم التشريح والاجنة، كلية الطب، جامعة بنها

"قسم وظائف الأعضاء، كلية الطب، جامعة بنها

الرصاص هو أحد المعادن الثقيلة التي لها العديد من الآثار الجانبية على الأعضاء المختلفة. في الآونة الأخيرة ، أصبح العق بين كل من الرجل و المر أة مصدر قلق كبير. يستخدم زرع الخلايا الجذعية الوسيطة إلى العضو التناسلي الذكري لعلاج الأمر اض المختلفة. لار اسة التباينات الهيكلية المجهرية والتحديد الهيتوكيمايى المناعى للكاسبيز ب كدليل لموت الخلايا المبرمجة و الاستجابةً لآثار زرع الخلايا الجذعية الوسيطة (MSCs) على قلة السائل المنوى المستحدث فى ذكور الجرذان. تم تقسيم ثلاثون من ذكور الجرذان البا لغة بالتساوي إلى؛ المجموعة الأولى (المجموعة الضابطة)، المجموعة الثانية (التي تحقن في الوريد بجر عة واحدة من نتر ات الرصاص (ب. بr ملغم / كغم من وزن الجسم) و المجمو عة الثالثة التسمم بالرصاص مع حقن الخلايا الجذعية الوسيطة (تم حقن الخلايا الجذغية الوسيطة عن طريق الوريد لمدة ستة أسابيع). ثم اخذت عينات من كل خصية للتحليل النسيجي و المناعي في نهاية الدر اسة. كثنت نتائجنا أن جودة السائل المنوي و مستو يات هرمون تستو ستيرون تأثرت بشكل كبير بعد التعرض للتسمم بالرصاص ومع الفحص النسيجي وجد انه هنالك توزيع غير طبيعي للخلايا المنوية، والإفر اغ وانفصال الخلايا من الغثاء المبطن بالمقارنة مع المجمو عة الضابطة. و أظهرت الدر اسة المناعية ارتفاع كبير في شدة صبغة كاسباس ب في خلايا كل من سيرتولي، لايدج، والخلايا الاولية وذللك بالمقارنة مع المجموعة الضابطة. وبعد حقن الخلايا الجزعية الوسيطة لوحظ زيادة جزئية في نو عية الحيو انات المنوية مع تحسن ملحوظ في التغيرات النسيجية في الخصية وكذلك انخفاض في عدد

الخلايا المناعية كسابيس نستتنج من هذة الدر اسة ان الخلايا الجزعية الوسيطة تمنع جزئيًا التغيرات النسيجية التي احدتثها سمية الرصاص ، مما يوحي بأن استخدام الخلايا الجزعية الوسيطة قد يعطي الأمل في علاج العقم عند الذكور. 